\title{
Methodical basis of training of cadets for the military applied heptathlon competitions
}

\author{
Anatskyi R.V. ${ }^{1}$, Kolomiitseva O.E. ${ }^{2}$, Cretu M. ${ }^{3}$, Potop V. ${ }^{4}$ \\ ${ }^{1}$ The National Academy of the National Guard of Ukraine, Ukraine \\ ${ }^{2}$ Yaroslav Mudryi National Law University, Ukraine \\ ${ }^{3}$ University of Pitesti, Romania \\ ${ }^{4}$ Ecological University of Bucharest, Romania
}

\begin{abstract}
Purpose:

Material:

of the research is to develop methodical bases of training of cadets for the military applied heptathlon competitions.

Cadets of $2-3$ courses at the age of $19-20$ years $(n=20)$ participated in researches. Cadets were selected by the best results of exercises performing included into the program of military applied heptathlon competitions (100 m run, $50 \mathrm{~m}$ freestyle swimming, Kalashnikov rifle shooting, pull-up, obstacle course, grenade throwing, $3000 \mathrm{~m}$ run). Preparation took place on the basis of training center. All trainings were organized and carried out according to the methodical basics: in a week preparation microcycle five days cadets had two trainings a day (on Saturday was one training, on Sunday they had rest). The selected exercises with individual loads were performed.

Results: $\quad$ Sport scores demonstrated top results in the performance of $100 \mathrm{~m}$ run, $3000 \mathrm{~m}$ run and pull-up. The indices of performing exercise "obstacle course" were much lower than expected. Rather low results were demonstrated in swimming and shooting.

Conclusions: Results of researches indicate the necessity of quality improvement: cadets' weapons proficiency; physical readiness to perform the exercises requiring complex demonstration of all physical qualities.

Keywords: $\quad$ cadets, military, applied, heptathlon, physical, fire, readiness.
\end{abstract}

\section{Introduction}

The competitions in different directions of future professional activity take a certain place in structure of cadets' training of military educational institutions. Military applied heptathlon competitions are the most difficult among them. Such competitions allow to estimate the cadets' training level. They require demonstration of the maximum physical and psychological skills by cadets.

Cadets' future professional activity provides a possible participation in regime and force actions [7]. Therefore the problem of cadets' high-quality training is still particularly essential. Increase of loads of cadets' vocational physical training couldn't provide the solution of the application tasks [3]. The different researches indicate the requirement of cadets' good physical training [8]. According to O. Rolyuk's opinion [11] the military man must have physical endurance, strength, speed, accuracy, reliability of actions in the conditions of time's deficit and absence of additional information. Other researches were aimed at the development of cadets' applied physical qualities for effective implementation of fight's methods [16]. Authors mark that increase in level of special endurance of cadets-fighters should be carried out simultaneously with improvement of the general physical training [14]. In other research [17] were defined typical mistakes done by cadets during mastering submission hold. Authors considered improvement of training's methods with a point of view of advanced theoretical researches devoted to processes of movements' regulation. Such approach allowed to improve considerably the quality of cadets' training. It is possible to use complex technique of cadets' training [15]. Authors recommend to combine subjects of vocational training: physical, tactical training and weapons proficiency. Multiathlon and battle

(C) Anatskyi R.V., Kolomiitseva O.E., Cretu M., Potop V., 2017 doi:10.15561/20755279.2017.0601 marches on different distances are effective activities to improve physical, moral and volitional powers of cadets. Such trainings contain various obstacles (high-rise constructions, ferryings, firing lines, etc.) $[15,19]$. It is determined that the long stay in conditions of positional defense is not a problem for implementation of military men requirement for physical improvement [18].

The important components of cadets' training are the followings: appropriate organization of pedagogical control [30]; choice of adequate and reliable tests [28, 42]; optimization of physical loads [21, 35]; planning of preparation cycles of taking into account the morphofunctional features of an organism [38, 40].

It is possible to distinguish the following directions of cadets' training: approaches to increase the level of special and general endurance [23, 29, 33]; basics of nutrition [26] and its influence on body weight [32]; physical rehabilitation and prophylaxis of traumatism during physical exercises' performance [41]; keeping of healthy lifestyle [34]; influence of various factors on motor behavior of a person [25, 27]; methodological provision of training's quality $[31,39,46]$; satisfaction of sports activity $[44,45]$; individual approach to difficult exercises training [36, 37, 47];

It is necessary to consider that cadets' weapons proficiency depends on psychophysiological features of person [22, 24, 43].

The modern military applied heptathlon is notable for exceptional complexity. Each of its types can significantly affect the general result of competitions $[15,19]$. As a rule, the training process is rather difficult. It is connected with the requirement of training's camps organization, existence of necessary material resources. Proficiency level of specialists in all types of training is also important.

The analysis of scientific literature allows to confirm that the major factor is absence of methodical basics 
of studying and training process creation of cadets' preparation for complex competitions.

The purpose of the research is to develop methodical bases of training of cadets for the military applied heptathlon competitions.

\section{Material and methods.}

Participants. Cadets of 2-3 courses at the age of 19-20 years $(n=20)$ participated in researches.

Organization of researches. The research had two stages. The first stage corresponded to the preparatory period. Tasks of that stage were the following:

1. carrying out of preliminary monitoring of cadets' readiness level by seven types of multiathlon;

2. preparation for competitions;

3. selection of cadets for competitions according to the results of the current monitoring.

This stage was carried out into the training center. At this stage all trainings were organized and were carried out according to the methodical bases of preparation:

- rational week distribution of training load by types of multiathlon for cadets of military educational institution (tab. 1) was made;

- within one training exercise the shooting were carried out only after exercises in swimming;

- exercises in swimming and shooting weren't crossed with exercises in grenade throwing;

- in a week microcycle of preparation five days cadets had two trainings a day (on Saturday was one training, on Sunday they had rest);

Individualization of load considered evaluation method of multiathlon types fulfillment and results, and also the current physical state of cadets. To the development of these methodical basics we have come after the analysis of cadets' participation experience in competitions in separate types of multiathlon.

Preparation for the first type of the competitions "100 m run" consisted of the following exercises: start from different poses: front lying position with bent arms; back lying position; front lying position; squat position face and a back towards movement; squat position back towards movement jumping squat with turn on $180^{\circ}$; squat position back towards movement jumping squat with turn on $360^{\circ}$; run downhill; run downhill on sand; run downhill on sand with weighted (a car tire - the rope with car tire or carryall bag of sand were bound to a belt); run on a distance with partner as weighted; jumping exercises (jumping squat with advance forward, jumps on the right leg with advance forward and pulling of the left leg to a breast up, the same for the left leg); run (10-30 m flying start, $30 \mathrm{~m}, 60 \mathrm{~m}, 100 \mathrm{~m})$, The main method of exercises fulfillment was repeated one [4].

Preparation for the second type of multiathlon "50 $\mathrm{m}$ freestyle swimming" was carried out on the course of an open waters and consisted of the following exercises: 25-50 m freestyle swimming, practice of turn and start. Interval and repeated methods were used to perform these exercises [4].

In competitive exercise "shooting from a military weapon" Kalashnikov (exercise of AK-1) was used. This exercise consists of three trial shots and ten exam shots. During cadets' training were used: training in preparation for shooting from small weapons from different positions. After that preparation was directed to practice of exercises of basic shooting from small weapons. Exercises of basic shooting consist of shooting from different positions: shooting from prone position; shooting from standing on one knee position; firing from standing position ( 3 shots from each position). Further exercises of basic shooting were executed, including fast shooting, from personal weapon (AK-1). Preparation finished by trainings and execution of special exercises of shooting from personal weapon (AK-1). Special exercises of shooting consist of firing from different positions: prone, knee, standing of 5 shots from each position.

The "Pull-up" exercise was the fourth type of multiathlon. During cadets' training the following exercises were used: hip-swing-up; muscle-up; armpumping exercises (support on parallel bars, front lying support, front lying support weighted - with carryall bag of sand on the back); movement on hands on parallel bars; movement on straight arms on parallel bars (to hold legs cross); bench pressing ( $70-80 \%$ of body weight).

Passing of obstacle course demands from cadets fulfillment of traditional set of exercises: to throw $600 \mathrm{~g}$ grenade from dug position on $20 \mathrm{~m}$ on a wall (breaches) or on $1 \times 2,6 \mathrm{~m}$ field before a wall (direct hit is ruled valid; missing the hit by the first grenade to continue throwing - no more than three grenades before target hit); to jump out of trench; $100 \mathrm{~m}$ run on the track in the direction to the start; to run around a flag; $20 \mathrm{~m}$ run and to jump over 2,5 $\mathrm{m}$ wide fire trench; to run through the maze; to climb

Table 1. Week distribution of a training load by types of multiathlon

\begin{tabular}{|c|c|c|c|c|c|c|}
\hline \multirow[t]{2}{*}{ Type of competition exercise } & \multicolumn{6}{|c|}{ Days of week } \\
\hline & Monday & Tuesday & Wednesday & Thursday & Friday & Saturday \\
\hline 100 m run & & + & & + & & \\
\hline 50 m freestyle swimming & + & & + & & + & \\
\hline Military weapon shooting (AK-1) & + & & + & & + & \\
\hline Pull-up & + & & + & & + & + \\
\hline Obstacle course & & + & & + & & \\
\hline Grenade throwing F-1 & & + & & + & & + \\
\hline 3000 m run & & + & & + & & + \\
\hline
\end{tabular}


over a fence, to climb on a vertical ladder on the second segment of the destroyed bridge; to run on the bars, to skip on the other bar, to jump off on the land from a standing position from the end of the last segment of the bar; to overcome three steps of the destroyed ladder (mandatory contact with two legs of the land between steps), to run under the fourth step; to creep in a wall breach; to jump down in a trench, to pass on a trench; to jump out of a well; a jump to overcome a wall; to run up an inclined ladder on the fourth step and to run down on steps of the destroyed ladder; to climb on a vertical ladder on the bar of the destroyed bridge, to run on the bar (bars are located sequentially at small distance from each other), to run down on inclined board; to jump over $2 \mathrm{~m}$ wide fire trench; to run $20 \mathrm{~m}$, to run around the flag, to run $100 \mathrm{~m}$ in the opposite direction on the track to the finish. Total length of an obstacle course is $400 \mathrm{~m}$. The main method of training is repeated. Each element and exercise was practiced individually and in complex.

The next type of multiathlon was grenade throwing. There were some difficulties. Cadets practically did not know technique of running start and swing. The personal optimum distance of running start for effective fulfillment of a throw was selected. The main method of exercises fulfillment was repeated.

Final type of multiathlon is $3000 \mathrm{~m}$ run. For effective preparation for this type of competitions was used socalled "sidestep" run: $1 \mathrm{~km}-2 \mathrm{~km}-3 \mathrm{~km}-2 \mathrm{~km}-1$ $\mathrm{km}$ in case of the heart rate (HR) within 155-165 beats/ min. Run was fulfilled by a equal and variable methods. Besides cadets run 3-5 km in the same pulse mode.

The cadets' preparation and participation in competitions was carried out under the leadership of the physical training teachers and weapons proficiency teachers with profile education.

Protocols of competitions were analyzed during the researches: results of personal and team performances by each type of multiathlon. In pedagogical testing were applied standard test exercises for cadets: $100 \mathrm{~m}$ run and $3000 \mathrm{~m}, 50 \mathrm{~m}$ freestyle swimming, pull-up; obstacle course; grenade throwing; Kalashnikov rifle shooting. Pedagogical observation was carried out for improvement of training load value; detections of cadets mental response to the considerable physical activities; for determination of performance spirit in competitions.

Statistical analysis. The received results were processed by means of statistical soft Microsoft Excel with calculation of the following indices: arithmetic middling $(\mathrm{X})$; mean-square deviation $(\sigma)$, Student t-test (t).

\section{Results}

Results of the first stage of researches are provided into tab. 2. The analysis of results of fulfillment by cadets the first type of multiathlon $-100 \mathrm{~m}$ run confirms rather high level of high-speed and force abilities development. According to the standards for physical training for cadets of military educational institution [5] the average result of team much more exceeds the mark "excellent”.

There is a fact that in standards of physical training for cadets there is no swimming at all. There are only norms for overcoming a distance in full gear [5]. During preparation in swimming we were guided by results in sport. As a result the average result of each team in 50 $\mathrm{m}$ freestyle swimming is much lower, than demonstrate children of elementary sport school. Individual results of cadets were also very low.

Results of shooting are at the low level. Therefore preparation for this type of competitions requires special attention. The average result of team in pull up (the fourth type of competitions) is rather high and according to the standards [5] much more exceeds the mark "excellent". The average result of team during overcoming "obstacle course", in comparison with standards [5] exceeds mark "excellent".

Results of grenade F-1 throwing on distance demonstrate the lack of the appropriate method of performance. As a result, the most of cadets demonstrated rather low individual results. At the same time the average result of team in comparison with standards [5] corresponds to the mark "good”.

In $3000 \mathrm{~m}$ run cadets demonstrated rather high individual results: the average induce of team in comparison with standards [5] exceeds the mark "excellent”.

The above mentioned data confirmed that cadets demonstrate higher results in the following types of multiathlon: $100 \mathrm{~m}$ and $3000 \mathrm{~m}$ run, pull-up, obstacle course. The lower results in $50 \mathrm{~m}$ freestyle swimming, grenade throwing and shooting were noted. It can lead to loss of scores in all-team competition. Results of preliminary monitoring allowed to reveal weaknesses and strengths of cadets physical training and weapons proficiency, their moral and strong-willed spirit. It allowed

Table 2. Results of cadets' preliminary monitoring fulfillment of seven types of sport applied multiathlon, $(n=20)$

\begin{tabular}{lll}
\hline Type of exercises & $\mathbf{X}_{\mathrm{am}}$ & $\boldsymbol{\sigma}$ \\
\hline $100 \mathrm{~m}, \mathrm{sec}$ & 13,2 & 0,4 \\
$50 \mathrm{~m}$ freestyle swimming, sec & 45,5 & 3,2 \\
AK-1 (shooting), scores & 75,8 & 10,4 \\
Pull-up, times & 19,4 & 1,3 \\
Obstacle course, min, sec & 2,02 & 0,2 \\
Throw of grenade F-1, m & 38,3 & 1,2 \\
$3000 \mathrm{~m}, \mathrm{~min}, \mathrm{sec}$ & 11,10 & 0,36 \\
\hline
\end{tabular}


Table 3. Results of cadets' preparation and performance in military applied heptathlon competitions

\begin{tabular}{|c|c|c|c|c|c|c|c|}
\hline \multirow[t]{2}{*}{ Type of exercises } & \multicolumn{2}{|c|}{$\begin{array}{l}\text { Current control, } \\
n=10\end{array}$} & \multicolumn{2}{|c|}{ Final control, $n=10$} & \multirow[t]{2}{*}{$T_{1-2}$} & \multirow[t]{2}{*}{$p_{1-2}$} & \multirow[t]{2}{*}{ Team's place } \\
\hline & $x_{1}$ & $\sigma_{1}$ & $x_{2}$ & $\sigma_{2}$ & & & \\
\hline $100 \mathrm{~m}$ run, sec & 12,95 & 0,3 & 12,68 & 0,3 & 0,64 & $>0,05$ & 1 \\
\hline $50 \mathrm{~m}$ freestyle swimming, sec & 42,40 & 2,3 & 39,46 & 2,84 & 0,81 & $>0,05$ & 6 \\
\hline AK-1 (shooting), scores & 82,6 & 11,3 & 68,9 & 16,32 & 0,69 & $>0,05$ & 6 \\
\hline Pull-up, times & 22,2 & 2,4 & 22,7 & 2,84 & 0,13 & 0,05 & 1 \\
\hline Obstacle course, min, sec & 1,52 & 0,4 & 1,58 & 0,31 & 0,12 & $>0,05$ & 4 \\
\hline Grenade F-1 throw, m & 40,15 & 1,62 & 43,14 & 2,79 & 0,92 & $>0,05$ & 4 \\
\hline $3000 \mathrm{~m}$ run, min, sec & 10,55 & 0,15 & 10,42 & 0,41 & 0,30 & $>0,05$ & 2 \\
\hline
\end{tabular}

to define tasks of the preparatory and competitive periods, to develop a technique of preparation for the forthcoming competitions.

The carrying out the preparatory period on the basis of training center allowed to apply wider arsenal of preparatory exercises. Use of different modifications of exercises in run and jumps on sand, down the hill, with weighted, etc. contributed to the development of physical and moral and strong-willed qualities of cadets.

At the end of the preparatory period the current monitoring was carried out. 10 cadets were selected for participation in the military applied heptathlon competitions. Results of the current monitoring and results of competitions are provided into tab. 3 .

The table 3 testifies that during preparation period cadets substantially improved the results in the following disciplines of multiathlon: $100 \mathrm{~m}$ and $3000 \mathrm{~m}$ run, $50 \mathrm{~m}$ swimming, grenade throwing on a distance. At the same time the team of National Academy of the National Guard took the 5th place following the results of competitions. The general result was substantially affected by low result in exercise "50 $\mathrm{m}$ freestyle swimming" and the considerable errors in shooting.

\section{Discussion.}

The analysis of scientific and methodical literature of the last few years can be argued that in preparation of cadets training camps organize and carry out only for sport teams. Most often it is fighting types of single combats $[14,16,17]$. At the same time the technology of preparation for different types of multiathlon is almost lost. The analysis of curricula demonstrates a priority of theoretical subjects of a humanitarian profile over practical disciplines. Thereby the number of physical education classes and cadets' sport training is reduced.

Preparation for participation in competitions includes physical, technical and psychological training. We developed the methodical basics of preparatory period organization of preparation for participation in military applied heptathlon competitions which helped to lead substantially physical capacities of cadets to the required level. Obtained data confirm a first priority of physical fitness level factor in support of personal combat readiness of cadets. It is also confirmed by other researches $[1,11$, 13]. Data on relevance of cadets' basic physical training factor are added $[13,18]$. Results of competitions testify to the problem of cadets' psychological readiness for fulfillment tasks similar to the military mission.

It was important to use in the training activities the specific means and methods of training; simulations of the most serious conditions of military multiathlon. Also during training process the current results of cadets were compared with predicted ones. When results had some discrepancies the value and directivity of a training load was improved.

Total control was carried out during prestarting preparation period on next to last week. The fact that preparation was fulfilled in field conditions was considered and there was no opportunity to hold preliminary competitions with strong rivals. It would help to set cadets up for variability of fight methods in different types of multiathlon from the psychological point of view [12].

The results received during the competitions demonstrate their improvement in comparison with preliminary ones. Results of exercises "shooting" and "obstacle course" during competitions were worse than during preliminary period. Comparison of results of preliminary, current and total control testifies the increase of indicators which doesn't have reliable character $(\mathrm{p}>0,05)$.

In the conditions of an open waters there isn't opportunity of practice turns and start. This factor is an important component of good result in swimming [9].

The cadets often make mistakes passing an obstacle course; this makes result of exercise performance worse. Therefore work on prevention of possible mistakes, training of each element technique and obstacle course in general was fulfilled $[1,19]$. Nevertheless, cadets during the competitions couldn't confirm the preliminary results. In our opinion, the psychological factor during fulfillment a difficult set of exercises ("obstacle course") plays an important role.

Today training of cadets for different types of competitions (in particular similar to combat-field conditions) cause some difficulties. Shooting is the specific type demanding special preparation. An opportunity to use in competitions a military weapon is followed by difficulties with its transportation and protection. There are also not enough bullets for training. The following factors have significant influence on results of shooting: 
cadet's psychological features; skeletal muscles tension; chosen speed and a rhythm of shooting $[2,6]$.

\section{Conclusions:}

1. The analysis of references testifies that teachers in higher education institutions of a military profile have accumulated work experience of cadets' training for profession basics. However there are losses in complex techniques of teaching profile subjects: physical training and weapons proficiency. It influences significantly on the process of cadets' training.

2. Results of researches testify the necessity to increase quality of cadets' weapons proficiency; physical readiness to perform the exercises demanding complex demonstration of all physical qualities.

\section{Conflict of interests}

The authors state that there is no conflict of interest.

\section{References}

1. Anatskyi RV, Kolomiitseva OE. Indicators of control exercise performance on the obstacle course by cadets KMB. Slobozhans'kij naukovo-sportivnij visnik,. 2014;6(44):7-10. (in Ukrainian)

2. Zhukovskij V, Kovalev S, Petrov I. Gun in close combat: Shooting anatomy. Moscow: AST Publishing House, Heleos; 2004. (in Russian)

3. Kompaniets YuA. Analysis of the state of the system of physical training of future law enforcement officers and perspective directions of its improvement. Pedagogics, psychology, medical-biological problems of physical training and sports, 2012;9:48-52.

4. Krucevich TIu. Theory and technique of physical training Kiev: Olympic Literature; 2003. (in Russian)

5. Leshchenia SV, Orlenko IP, Meleshko AO, Zabrods'kij SS. The instruction on the physical training organization in National Guard of Ukraine. Kiev; 2014. (in Ukrainian)

6. Mokreiev VI, Grekov VP, Radchenko IO, Kalita OM. How to increase the shooting efficiency from small weapon during single fire. Zbirnik naukovikh prac' Nacional'noi akademii Nacional'noi gvardii Ukraini. 2017;1(29):64-68. (in Ukrainian)

7. Nazarenko OL, Drobakha GA. Formalization of a problem of choosing the rational application methods for small unit of National Guard of Ukraine for the termination of mass riots. Chest' i zakon. 2017; 1(60): 38-45. (in Ukrainian)

8. Okipniak DA, Okipniak AS, Zubal' MV. Technique of professional competence formation at future specialists in mine clearing. Fizichne vikhovannia, sport i zdorov'ia liudini. 2017; 10: 374-383. (in Ukrainian)

9. Nechunaev IP. Swimming. Moscow: EKSMO; 2013. (in Russian)

10.Platonov VN.. Periodization of a sports training. Kiev: Olympic Literature; 2014. (in Russian)

11. Roliuk O. Special physical training of the military personnelintelligence agents. Fizichne vikhovannia, sport i kul'tura zdorov'ia u suchasnomu suspil'stvi. 2016; 1 (33): 57-63. (in Ukrainian)

12.Samolenko TV. Technique sports training individual planning of high qualified athletes specialized in middle distance races and long-distance races. Moscow: Sport; 2016. (in Russian)

13.Yavorskyy AI. Study of author's applied physical training program for military officers-graduates of reserve officers' departments. Pedagogics, psychology, medical-biological problems of physical training and sports, 2016; 20(2): 72-77. doi:10.15561/18189172.2016.0211

14.Alekseev NA, Kutergin NB, Kulinichev AN, Gorbatenko AV. Integrated method development of general and special students stamina involved in the fight. Physical Education of Students, 2014; 3:3-8. doi:10.6084/m9.figshare. 974476

15.Anatskyi RV., Kolomiitseva OE. Assessment of official combat mission's fulfillment by higher educational.
Pedagogics, psychology, medical-biological problems of physical training and sports. 2016; 4:4-10. doi. org/10.15561/18189172.2016.0401

16.Ashkinazi SM, Kochergin AN. Analysis of effectiveness of different hand to hand combat tactic variants. Uchenye zapiski universiteta im. P.F. Lesgafta, 2008;3:10-13. (in Russian)

17.Danylchenko VA, Khabinets TA. Typical mistakes, made by the cadets, mastering the submission locks, of the higher educational establishments of the Ministry of Internal Affairs of Ukraine. Physical Education of Students, 2014;4:20-25. doi:10.6084/m9.figshare. 974478

18.Hlazunov SI. Peculiarities of military officers' physical perfection during troops' being in conditions of positional defense. Pedagogics, psychology, medical-biological problems of physical training and sports, 2016; 20(1): 13-18. doi:10.15561/18189172.2016.0102

19.Mykhaylov VV, Mykhaylov VV, Popovich O.I. Running and tactical skill assessing in obstacle course run of Military Sports Complex's athletes. Pedagogics, psychology, medical-biological problems of physical training and sports, 2010;2:89-92.

20.Zakorko IP. Special physical training in higher educational establishments of MAF of Ukraine, considering individual features of cadets' motor abilities. Cand. Diss., Kiev; 2001. (in Ukrainian)

21.Arziutov G, Iermakov S, Bartik P, Nosko M, Cynarski WJ. The use of didactic laws in the teaching of the physical elements involved in judo techniques. Ido Movement for CultureJournal of Martial Arts Anthropology, 2016;16(4):21-30. doi:10.14589/ido.16.4.4

22.Broglio SP, McCrea M, McAllister T, Harezlak J, Katz B, Hack D, et al. A National Study on the Effects of Concussion in Collegiate Athletes and US Military Service Academy Members: The NCAA-DoD Concussion Assessment, Research and Education (CARE) Consortium Structure and Methods. Sports Medicine. 2017;47(7):1437-1451. doi:10.1007/s40279-017-0707-1

23.Danilowicz-Szymanowicz L, Szwoch M, Ratkowski W, Gutknecht P, Zagozdzon P, Opielowska-Nwak B, et al. A 100 km Run Does Not Induce Persistent Predominance of Sympathetic Activity During 24-Hour Recovery in Amateur Male Athletes. Hellenic Journal of Cardiology. 2015;56(3):271-2.

24.Delahaij R, Van Dam K. Coping with acute stress in the military: The influence of coping style, coping selfefficacy and appraisal emotions. Personality and Individual Differences. 2017;119:13-18. doi:10.1016/j.paid.2017.06.021

25.Dobrescu T, Moldovan E, Enoiu RS, Cretu M. The influence of cheerleading extracurricular activities on the motor behavior of middle-school pupils. In: Laborda JC, Ozdamli F, Maasoglu Y, editors. 5th World Conference on Educational Sciences. Procedia Social and Behavioral Sciences. 116. 
2014. p. 1950-1954.

26.Gmiat A, Mieszkowski J, Prusik K, Prusik K, Kortas J, Kochanowicz A, et al. Changes in pro-inflammatory markers and leucine concentrations in response to Nordic Walking training combined with vitamin D supplementation in elderly women. Biogerontology 2017:1-14. doi:10.1007/s10522017-9694-8

27.Grigore V, Gavojdea AM, Potop V. Analysis on Biomechanical Characteristics of Dismounts in Salto Backward Stretched Landings, in Balance Beam Event. 4th International Congress of Physical Education, Sport and Kinetotherapy (Icpesk 2014). 2015:125-130.

28.Hilgenberg FE, Santos A, Silveira EA, Cominetti C. Cardiovascular risk factors and food consumption of cadets from the Brazilian Air Force Academy. Ciencia \& Saude Coletiva. 2016;21(4):1165-1174. doi:10.1590/141381232015214.15432015

29.Jastrzębski Z, Zychowska M, Jastrzębska M, Prusik K, Prusik K, Kortas J, et al. Changes in blood morphology and chosen biochemical parameters in ultra-marathon runners during a 100-km run in relation to the age and speed of runners. International Journal of Occupational Medicine and Environmental Health, 2015;29(5): 801-814. doi:10.13075/ ijomeh.1896.00610

30.Khudolii OM, Ivashchenko OV, Iermakov SS, Rumba OG. Computer simulation of junior gymnasts' training process. Science of Gymnastics Journal. 2016;8(3):215-228.

31.Kopeikina EN, Drogomeretsky VV, Kondakov VL, Kovaleva MV, Iermakov SS. Modification of harvard step-test for assessment of students' with health problems functional potentials. Physical Education of Students. 2016;20(4):4450. doi:10.15561/20755279.2016.0405

32.Kortas J, Kuchta A, Prusik K, Prusik K, Ziemann E, Labudda $\mathrm{S}$, et al. Nordic walking training attenuation of oxidative stress in association with a drop in body iron stores in elderly women. Biogerontology 2017: 1-8. doi:10.1007/s10522-0179681-0

33.Kortas J, Prusik K, Flis D, Prusik K, Ziemann E, Leaver $\mathrm{N}$, et al. Re: Possible effect of decreased insulin resistance on ferritin levels after Nordic Walking training. Clinical Interventions in Aging, 2016;11:150-151.

34.Kortas J, Prusik K, Flis D, Prusik K, Ziemann E, Leaver N. Effect of nordic walking training on iron metabolism in elderly women. Clinical Interventions in Aging, 2015;10:1889-1896.

35.Kriventsova I, Iermakov S, Bartik P, Nosko M, Cynarski WJ. Optimization of student-fencers' tactical training. Ido Movement for Culture-Journal of Martial Arts Anthropology. 2017;17(3):21-30. doi:10.14589/ido.17.3.3

36.Osipov AY, Kudryavtsev MD, Iermakov SS, Jagiello W. Criteria for effective sports selection in judo schools - on example of sportsmanship's progress of young judo athletes in Russian Federation. Archives of Budo. 2017;13:179-186.
37.Osipov AY, Kudryavtsev MD, Iermakov SS, Jagiello W. Topics of doctoral and postdoctoral dissertations devoted to judo in period 2000-2016-the overall analysis of works of Russian experts. Archives of Budo. 2017;13:1-10.

38.Podrigalo LV, Iermakov SS, Jagiello W. Special indices of body composition as a criterion of somatic development of martial arts practitioners. Archives of Budo Science of Martial Arts and Extreme Sports. 2017;13:5-12.

39.Potop V. Methodology of Motor Learning Based on Transfer Technology in Women's Artistic Gymnastics. Tradition and Reform: Social Reconstruction of Europe. 2013:285-288.

40.Salgueiro DFD, Barroso R, Barbosa AC, Telles T, Andries O. Anthropometric Parameters of Cadets Among Different Military Sports. International Journal of Morphology. 2015;33(3):831-834.

41.Scott SA, Simon JE, Van Der Pol B, Docherty CL. Risk Factors for Sustaining a Lower Extremity Injury in an Army Reserve Officer Training Corps Cadet Population. Military Medicine. 2015;180(8):910-916. doi:10.7205/ milmed-d-14-00618

42.Souza LAS, Torres ARR, Barbosa GA, de Lima TJS, de Souza LEC. Subjective Well-Being and Burnout in Military Cadets: The Mediating Role of Self-Efficacy. PsicologiaReflexao E Critica. 2015;28(4):744-752. doi:10.1590/16787153.201528412

43.Tomczak A, Dabrowski J, Mikulski T. Psychomotor performance of Polish Air Force cadets after 36 hours of survival training. Annals of Agricultural and Environmental Medicine. 2017;24(3):387-391. doi:10.5604/12321966.1232762

44.Zarebska A, Jastrzebski Z, Moska W, Leonska-Duniec A, Kaczmarczyk M, Sawczuk M, et al. The AGT Gene M235T Polymorphism and Response of Power-Related Variables to Aerobic Training. Journal of Sports Science and Medicine. 2016;15(4):616-24.

45.Ziolkowski A, Zubrzycki I, Blachnio A, Drobnik P, Zaranska $\mathrm{B}$, Moska W. Influence of sport activity on satisfaction with life and sense of coherence among physically disabled people. Baltic Journal of Health and Physical Activity. 2016;8(4):109-16.

46.Stan Zenovia, Baştiurea Eugen, Mihailă Ion, Crețu Marian. Correlation between the muscle strengths of the trunk and upper limbs. Journal of Physical Education and Sport, 2016; 16(4): 1298 - 1303. doi:10.7752/jpes.2016.04206

47.Ulareanu Marius Viorel, Potop Vladimir. Synchronization of biomechanical indicators of clean and jerk style key elements in performance weightlifting. Journal of Physical Education and Sport, 2017;17(Suppl.5): 2350 - 2355. doi:10.7752/ jpes.2017.s5258 
Information about the authors:

Anatskyi R.V.; http://orcid.org/0000-0002-5662-9903; ruslan.anackii@mail.ru; The National Academy of the National Guard of Ukraine; Povstannya Square 3, Kharkov, 61001, Ukraine.

Kolomiitseva O.E.; http://orcid.org/0000-0003-4463-5027; kolomiitseva7@ukr.net; Yaroslav Mudryi National Law University; Pushkinskaya street, 77 Kharkov, 61024, Ukraine.

Cretu Marian; http://orcid.org/0000-0003-1934-0534; marian.cretu@efsupit.ro; University of Pitesti: Pitesti, arges, Romania; Str. Targul din Vale, nr.1, 110040 Pitesti, Arges, Romania.

Potop Vladimir; http://orcid.org/0000-0001-8571-2469; vladimir_potop@yahoo.com; Ecological University of Bucharest; Bulevardul General Vasile Milea 1G, București 061341, Romania.

Cite this article as: Anatskyi RV, Kolomiitseva OE, Cretu M, Potop V. Methodical basis of training of cadets for the military applied heptathlon competitions. Physical education of students, 2017;21(6):255-261. doi:10.15561/20755279.2017.0601

The electronic version of this article is the complete one and can be found online at: http://www.sportedu.org.ua/index.php/PES/issue/archive

This is an Open Access article distributed under the terms of the Creative Commons Attribution License, which permits unrestricted use, distribution, and reproduction in any medium, provided the original work is properly cited (http://creativecommons.org/licenses/by/4.0/deed.en).

Received: 11.06.2017

Accepted: 04.07.2017; Published: 08.12.2017 